Date of publication: December 28, 2021

DOI: 10.52270/26585561_2021_12_14_113

Historical Sciences

\title{
RUSSIAN ORTHODOX CHURCH DURING THE PERIOD 1917 REVOLUTION
}

\author{
Ershov, Bogdan Anatolievich ${ }^{1}$ \\ 'Doctor of Historical Sciences, Professor, Academician of RAE, Voronezh State Technical University, \\ 20 years of October street, 84, Voronezh, Russia, E-mail: bogdan.ershov@yandex.ru
}

\begin{abstract}
Theoretical and practical aspects of the problem of state-church relations are now increasingly attracting public attention. In this regard, one of the most important tasks is to study the historical experience of the relationship between the state, the Church and believers, which allows us to use the experience of the past in the formation of a modern model of church-state relations. The study of the experience of self-determination of the Orthodox Church on the issue of relations with the state during the revolution of 1917 is currently of considerable scientific and practical interest.
\end{abstract}

Keywords: church, society, state, person, religion.

\section{INTRODUCTION}

The problems of church-state relations, ideological and practical aspects of the reforms were actively discussed in the spring and summer of 1917 in church journalism, at meetings and congresses of the clergy and laity. June 12 - August 1, the Pre-Council Council worked in Petrograd. The Local Council, which opened on August 15 in Moscow, was supposed to express how the Orthodox Church wished to see its relations with the new state, the final organization of which was postponed until the Constituent Assembly. On December 2, the Local Council adopted a ruling on the legal status of the Russian Orthodox Church in the state, which was a church bill for the Constituent Assembly. The definition was the result of the internal church discussion of the problem and the official position of the Church on the issue of relations with the state. The relevance of the topic lies both in the academic interest in the topic, and in the public-church attention to the problems of church-state relations. Recently, the influence of the Russian Orthodox Church on the life of the state and society has grown. There is a process of reforming state legislation that determines the interaction between the state and religious organizations in the field of education and spiritual and moral education of young people, the protection and use of cultural and artistic monuments. The prospects for reforming state legislation in the field of protecting freedom of conscience and religion, which determines the legal status and status of the Russian Orthodox Church and other traditional religions in modern Russia, are also being actively discussed. These issues are no less actively discussed by the church community.

In 2000, the Council of Bishops of the Russian Orthodox Church adopted the Fundamentals of the Social Concept of the Russian Orthodox Church, a separate section of this document reveals the conceptual church position on the issue of relations with the state. 


\section{METHODOLOGY AND DISCUSSION}

There are very few special comprehensive monographic studies devoted to the history of the formation of the position of the Russian Orthodox Church on the issue of relations with the state after the February Revolution. However, the topic was touched upon by many researchers both in the general context of studying church-state relations and church history of Russia in the XX century, and in the development of individual plots, for example, when studying the activities of the Local Council of 1917-1918 or the initial period of Soviet religious policy, in particular, the preparation of a decree on the separation of Church and state.

In the works of historians, the basic principles and theses were formulated, on which the Soviet historiography of the problem was later based. In general terms, this concept is presented as follows: The Provisional Government financed and protected the Church, and it served as its ideological support. The Orthodox Church was seen as a class ally of the bourgeoisie and the bourgeois Provisional Government. According to Soviet historians, the Church and clergy were counter-revolutionary in their essence, and the Local Council of 1917-1918 became the headquarters of the church counter-revolution. So, N.M. Lukin argued: "The bourgeoisie holds fast to the union of the church with the state, because the state church is one of the instruments of class domination of the bourgeoisie." According to P. Zarin, the Church supported the foreign and domestic policy of the Provisional Government aimed at suppressing the revolution, and in return received material support and protection of its privileges from the bourgeois government. The works of the leaders and ideologists of the Renovationist schism, priest A.I., Vvedensky and B.V. Titlinov stand apart. Their publication in Soviet Russia was conditioned by the state's support for renovationism, which explains the pro-Soviet tone of these publications, which aimed to prove the counterrevolution of the Orthodox episcopate of the patriarchal "Tikhon" Church.

They noted the compromise and contradictory nature of the religious policy of the Provisional Government, which did not take responsibility for the cardinal breakdown of church-state relations, which was partly explained by the influence of the conservative church environment. Thus, A.I. Vvedensky believed that in the spring of 1917 the government pursued the most radical policy in the religious sphere, which gradually lost its revolutionary character by the end of the summer of 1917 due to the complicated political situation, which was expressed, in his opinion, in the rapprochement of the government with conservative-minded circles of the Orthodox clergy. Remaining within the framework of the established idea of the class alliance of the Orthodox Church and the bourgeois Provisional Government, new observations were made by E.S. Osipova, who analyzed the positions of some congresses of clergy and laity on socio-political issues (including the problems of church-state relations) and came to the conclusion that the majority of the clergy sympathized with the Cadet party, but some of the clergy and laity, the Union of Democratic Clergy and part of the Rural clergy, focused on the Social revolutionaries.

In the 1980s, works appeared in which traditional approaches were somewhat reassessed, although there were no significant changes: the thesis of the class union of the Church and the Provisional Government prevailed, which sought to preserve and expand its privileges.

Thus, I.A. Kryvelev presented an objective characterization of the church's position on the issue of relations with the state. He wrote that "in the future, the leaders of the church envisioned such an order in which the cathedral, episcopal, and perhaps patriarchal church is independent of the state, but enjoys economic, political and any other support from it and occupies a preeminent central position in the state.

The methodology of the work includes both general scientific and special methods of historical research. The fulfillment of the tasks set in the study led to the use of a systematic approach, methods of analysis and synthesis. Special methods of historical research include problem-chronological, comparative-historical and synchronous methods. 


\section{RESULTS}

After the February Revolution, the Russian Orthodox Church, represented by the Holy Governing Synod, diocesan bishops, the majority of the clergy and active laity, recognized the Provisional Government. The hopes for positive changes in church life were pinned on revolutionary changes in church circles: a change in the existing system of church-state relations, an adjustment of the current government church policy, the convening of a Local Council and the implementation of urgent church reforms.

The renovationist part of the Russian church community supported the internal reform of the church organization, initiated by the Provisional Government and carried out by a series of events of the Holy Synod in the spring and summer of 1917. Simultaneously, and sometimes ahead of the events of the Holy Synod, local breakdown of the synodal system from below began in dioceses. As a result, as a result of synodal events and grassroots lawmaking of the clergy and laity, a transitional system of church government took shape. The old bodies of church administration and the courts of the department of the Orthodox confession (the Holy Synod, spiritual consistories) interacted with the institutions newly created on a church-public basis (church-diocesan and deanery councils, parish meetings and councils), while the existence of the latter was not in any way fixed in legislation at the government level.

Further implementation of a comprehensive church reform was associated with the work of the Local Council, which opened on August 15 in Moscow. The Provisional Government gave him the right to develop a bill on a new order of church administration and submit it for approval by the state authorities. The basic element of the upcoming church reform, on which the direction of further church reform depended, was to be the creation of a new model of church-state relations.

In the spring and summer of 1917 , in parallel with the church reform and the preparation of the Local Council, a discussion of the prospects for church-state relations began in church circles. The majority of church publicists, clergy and active laity spoke out against the complete separation of the Church from the state, subject to the autonomy of church government. There was a minority of principled supporters of church-state separation, who did not insist on the immediate implementation of the complete separation of the Church from the state, realizing the unpreparedness of the church organization for independent existence.

Professor P.V. Verkhovsky plays an important role in the formation of a promising model of church-tochurch relations by the Russian Orthodox Church. His ideas and practical proposals received the support of the majority of diocesan congresses of clergy and laity, and then were enshrined in the resolutions of the AllRussian Congress of Clergy and Laity on June 1-12.

The elaboration of the official church position became the subject of the Pre-Council Council and the first session of the Local Council (August - December 1917). The draft law was based on the provisions compiled by P.V. Verkhovsky, supplemented and edited. The result was a conciliar definition-a bill on December 2, 1917.

The essence of the conciliar definition: a cooperative model of church-state relations, which provided for the Orthodox Church the status of the first among equal religions in the state, the public-legal status of the church organization and its material support by the state. For its time, it was a progressive model of churchstate relations, focused on German and Austro-Hungarian legislation, according to its developers, which had precedents in foreign legislation.

At the Local Council, an attempt was made to create a conceptual document reflecting the Church's view on the theoretical and ideological aspects of church-state relations. Professor S.N. Bulgakov drew up a declaration "On the attitude of the Church to the state", aimed at an intra-church audience. It was heard at the plenary council meeting, but its planned detailed discussion and voting did not take place. As a result, the discussion of theoretical issues of church-state relations, which had begun earlier in the church press, did not receive final authoritative conciliar permission. Meanwhile, the idea of the union of the Orthodox Church and the state received the practical support of the majority of the members of the Local Council. 
However, the chances of practical implementation of the project proposed by the Local Council in the current political situation in Russia at the end of 1917 were small. The confident victory of the socialist parties in the elections to the Constituent Assembly made the prospect of a complete separation of Church and state more realistic. In the future, the dissolution of the Constituent Assembly by the Bolsheviks and the first measures of the Soviet government in the field of religious policy made the council bill unrealistic.

\section{CONCLUSION}

The Russian Orthodox Church met the February coup and the coming to power of the Provisional Government in "passive loyalty." Her view of her future position in Russia was formulated first at diocesan meetings (late March - May 1917), the All-Russian Congress of Clergy and Laity in Moscow (June 1-11, 1917) and then in the Pre-Council Council and at the Local Council. The majority of the clergy and lay believers spoke out, on the one hand, for the maximum non-interference of the state in the affairs of the church, and, on the other, for the preservation of Orthodoxy in Russia of a preeminent position among other religions.

By the autumn of 1917, the Russian Orthodox Church had become disillusioned with the capabilities of the government, which was unable to protect its interests in the conditions of the growing anticlerical movement. Its representatives focused their attention on the preparation of resolutions for the Constituent Assembly at the Local Council. This explains the calmness with which the clergy met the October revolution.

Despite the fact that all the activities of the Provisional Government were considered by contemporaries only as preparation for the Constituent Assembly, there was also an obvious strategic line in its church policy, going from internal church reforms (March-July 1917) through the destruction of the Department of the Orthodox Confession and its transformation into the Russian Orthodox Church proper (August-October 1917) to the gradual separation of church and state structures and the creation of an extra-confessional state.

\section{REFERENCE LIST}

Bakulin B. (1993) Untimely memories. Religion and democracy. On the Way to freedom of conscience. Moscow: Progress Group Publishing House. Pp. 149 - 163. (in Russ).

Bogolepov A.A. (1965) From the Holy Synod to the Holy Council of the Orthodox Russian Church. On Russian and general topics. New York. Pp. 95-158. (in Russ).

Dopmann Hans-Dieter. (1991) Die Orthodoxen Kirchen. Berlin. 384 p. (in Engl).

Dorskaya A.A. (1999) Russian lawmaking on freedom of conscience in 19051917. Problems of socioeconomic and political history of Russia of the XIX-XX century. Collection of scientific articles of memory. Alethea. Pp. 354-363. (in Russ).

Ershov B. A., Semenkova E. V. (2016) The consequences of the collapse of the Soviet Union. International Journal of Humanities and Natural Sciences. Vol. 3. Pp. 20-22. (in Russ). (in Russ).

Ershov B.A. (2010) The Russian Orthodox Church and secular power in the Voronezh province in the XIX - early XX centuries. GOU VPO "Voronezh State Technical University". Voronezh. 167 p. (in Russ).

Ershov B.A. (2010) The system of spiritual education in Voronezh province in the 19th century. Education and Society. Vol. 5 (64). Pp. 105-108. (in Russ).

Ershov B.A., Fursov V.N. (2018) The Russian Church in the State Mechanism of Russia. Bulletin SocialEconomic and Humanitarian Research. Vol. 1. Pp. 32-37. (in Engl). 
Ershov B.A., Perevozchikova L.S., Romanova E.V. (2019) Globalization and Intensification of Spiritual Values in Russia in the Philosophical Aspect. 6th International Conference on Education and Social Sciences Abstracts \& Proceedings. Pp. 208-212. (in Engl).

Ershov B.A., Perevozchikova L.S., Romanova E.V. (2019) Globalization and Intensification of Spiritual Values in Russia in the Philosophical Aspect. 6th International Conference on Education and Social Sciences Abstracts \& Proceedings. Pp. 208-212. (in Engl).

Ershov B.A., Volkova E.A., Frolova E.V., Volkov N.M., Pletnev V.I. (2019) The Revolution of 1905-1907. in Russia: results and consequences. 6th International Conference on Education and Social Sciences. Abstracts \& Proceedings. Pp. 213-220. (in Engl).

Firsov S.L. (1998) The financial situation of the Russian Church in the last pre-revolutionary decade. Church Historical Bulletin. Vol. 1. Pp. 145 - 161.

Frumenkova T.G. (1995) The Synod and the February Revolution. The Revolution of 1917: A collection of scientific articles. St. Petersburg: Third Russia. Pp. 27-34. (in Russ).

Kartashev A.V. (1995) The Provisional Government and the Russian Church. From the history of the Christian Church at Home and abroad in the XX century. Moscow: Krutitsky patriarchal compound. Pp. 9-21. (in Russ).

Korzun M.S. (1984) The Russian Orthodox Church in the service of the exploiting classes, X century 1917. Minsk: Belarus. 255 p. (in Russ).

Lyubimov N.A., protopresbyter. (1995) Diary of the meetings of the newly formed Synod (April 12, June 12, 1917). The Russian Church during the Revolution (1917 - 1918). Collection. M.: Krutitsky patriarchal compound. Pp. 15-120. (in Russ).

Malysheva S.Y. (2000) The Provisional Government of Russia. Modern Russian historiography. Kazan: Hater. 208 p . (in Russ).

Osipova E.S. (1964) The Church and the Provisional Government. Voprosy Istorii. 1964. Vol. 6. Pp. 6576. (in Russ). (in Russ).

Plaksin R.Yu. (1964) Church counter-revolution in the days of October. Voprosy Istorii. Vol. 11. Pp. 42-52.

Pospelovsky D.V. (1993) The Russian Orthodox Church: Trials of the beginning of the XX century. Questions of history. Vol. 1. Pp. 42-54. (in Russ).

Romanova E.V., Perevozchikova L.S., Ershov B.A. (2017) The Lifestyle of the Human Being in the Information Society. 3rd International Conference on Advances in Education and Social Sciences Proceedings of ADVED. Pp. 950-954. (in Engl).

Smirnov N.N. (1994) At the turning point: Russian teaching on the eve and in the days of the Revolution of 1917. St. Petersburg: Nauka. 410 p. (in Russ).

Smolitsch J. (1965) Die Russische Kirche in der Revolutionszeit vom Marz bis Oktober 1917 und das Landeskanzil 1917 bis 1918 (Zur Geschichte der Bezichen-gen zwischen Staat und Kirche in Russland). Ostkirche Studien. Vol. 4. Pp. 3-34. (in Engl).

Titlinov B.V. (1924) The Church during the Revolution. 192 p. (in Russ).

Vasilchikov I. (1971) My participation in the Local Church Council of the Russian Orthodox Church 19171918. A new journal. Vol. 102. Pp. 138-152. (in Russ). 


\title{
РУССКАЯ ПРАВОСЛАВНАЯ ЦЕРКОВЬ В ПЕРИОД РЕВОЛЮЦИИ 1917 ГОДА
}

\section{Ершов Богдан Анатольевич 1}

\author{
'Доктор исторических наук, профрессор, академик РАE, Воронежский государственный \\ технический университет, ул. 20-летия Октября, 84, Воронеж, Россия, \\ E-mail: bogdan.ershov@yandex.ru
}

\begin{abstract}
Аннотация
Теоретические и практические аспекты проблемы государственно-церковных отношений в настоящее время все больше привлекают внимание общественности. В связи с этим одной из важнейших задач является изучение исторического опыта взаимоотношений государства, Церкви и верующих, что позволяет использовать опыт прошлого при формировании современной модели церковно-государственных отношений. Изучение опыта самоопределения Православной Церкви по вопросу взаимоотношений с государством в период революции 1917 года в настоящее время представляет значительный научный и практический интерес.
\end{abstract}

Ключевые слова: церковь, общество, государство, человек, религия.

\section{СПИСОК ЛИТЕРАТУРЫ}

Bakulin B. (1993) Untimely memories. Religion and democracy. On the Way to freedom of conscience. Moscow: Progress Group Publishing House. Pp. 149 - 163. (in Russ).

Bogolepov A.A. (1965) From the Holy Synod to the Holy Council of the Orthodox Russian Church. On Russian and general topics. New York. Pp. 95-158. (in Russ).

Dopmann Hans-Dieter. (1991) Die Orthodoxen Kirchen. Berlin. 384 p. (in Engl).

Dorskaya A.A. (1999) Russian lawmaking on freedom of conscience in 19051917. Problems of socioeconomic and political history of Russia of the XIX-XX century. Collection of scientific articles of memory. Alethea. Pp. 354-363. (in Russ).

Ershov B. A., Semenkova E. V. (2016) The consequences of the collapse of the Soviet Union. International Journal of Humanities and Natural Sciences. Vol. 3. Pp. 20-22. (in Russ). (in Russ).

Ershov B.A. (2010) The Russian Orthodox Church and secular power in the Voronezh province in the XIX - early XX centuries. GOU VPO "Voronezh State Technical University". Voronezh. 167 p. (in Russ).

Ershov B.A. (2010) The system of spiritual education in Voronezh province in the 19th century. Education and Society. Vol. 5 (64). Pp. 105-108. (in Russ).

Ershov B.A., Fursov V.N. (2018) The Russian Church in the State Mechanism of Russia. Bulletin SocialEconomic and Humanitarian Research. Vol. 1. Pp. 32-37. (in Engl). 
Ershov B.A., Perevozchikova L.S., Romanova E.V. (2019) Globalization and Intensification of Spiritual Values in Russia in the Philosophical Aspect. 6th International Conference on Education and Social Sciences Abstracts \& Proceedings. Pp. 208-212. (in Engl).

Ershov B.A., Perevozchikova L.S., Romanova E.V. (2019) Globalization and Intensification of Spiritual Values in Russia in the Philosophical Aspect. 6th International Conference on Education and Social Sciences Abstracts \& Proceedings. Pp. 208-212. (in Engl).

Ershov B.A., Volkova E.A., Frolova E.V., Volkov N.M., Pletnev V.I. (2019) The Revolution of 1905-1907. in Russia: results and consequences. 6th International Conference on Education and Social Sciences. Abstracts \& Proceedings. Pp. 213-220. (in Engl).

Firsov S.L. (1998) The financial situation of the Russian Church in the last pre-revolutionary decade. Church Historical Bulletin. Vol. 1. Pp. 145 - 161.

Frumenkova T.G. (1995) The Synod and the February Revolution. The Revolution of 1917: A collection of scientific articles. St. Petersburg: Third Russia. Pp. 27-34. (in Russ).

Kartashev A.V. (1995) The Provisional Government and the Russian Church. From the history of the Christian Church at Home and abroad in the XX century. Moscow: Krutitsky patriarchal compound. Pp. 9-21. (in Russ).

Korzun M.S. (1984) The Russian Orthodox Church in the service of the exploiting classes, X century 1917. Minsk: Belarus. 255 p. (in Russ).

Lyubimov N.A., protopresbyter. (1995) Diary of the meetings of the newly formed Synod (April 12, June 12, 1917). The Russian Church during the Revolution (1917 - 1918). Collection. M.: Krutitsky patriarchal compound. Pp. 15-120. (in Russ).

Malysheva S.Y. (2000) The Provisional Government of Russia. Modern Russian historiography. Kazan: Hater. 208 p . (in Russ).

Osipova E.S. (1964) The Church and the Provisional Government. Voprosy Istorii. 1964. Vol. 6. Pp. 6576. (in Russ). (in Russ).

Plaksin R.Yu. (1964) Church counter-revolution in the days of October. Voprosy Istorii. Vol. 11. Pp. 42-52.

Pospelovsky D.V. (1993) The Russian Orthodox Church: Trials of the beginning of the XX century. Questions of history. Vol. 1. Pp. 42-54. (in Russ).

Romanova E.V., Perevozchikova L.S., Ershov B.A. (2017) The Lifestyle of the Human Being in the Information Society. 3rd International Conference on Advances in Education and Social Sciences Proceedings of ADVED. Pp. 950-954. (in Engl).

Smirnov N.N. (1994) At the turning point: Russian teaching on the eve and in the days of the Revolution of 1917. St. Petersburg: Nauka. 410 p. (in Russ).

Smolitsch J. (1965) Die Russische Kirche in der Revolutionszeit vom Marz bis Oktober 1917 und das Landeskanzil 1917 bis 1918 (Zur Geschichte der Bezichen-gen zwischen Staat und Kirche in Russland). Ostkirche Studien. Vol. 4. Pp. 3-34. (in Engl).

Titlinov B.V. (1924) The Church during the Revolution. 192 p. (in Russ).

Vasilchikov I. (1971) My participation in the Local Church Council of the Russian Orthodox Church 19171918. A new journal. Vol. 102. Pp. 138-152. (in Russ). 